\title{
XXXIV. On an omission in Clairaut's theory of the equilibrium of a homogeneous fluid; in some remarks on the 56th article of the "Bulletin des Sciences Mathematiques" for August 1830
}

James Ivory Esq. M.A. F.R.S.

To cite this article: James Ivory Esq. M.A. F.R.S. (1831) XXXIV. On an omission in Clairaut's theory of the equilibrium of a homogeneous fluid; in some remarks on the 56th article of the "Bulletin des Sciences Mathematiques" for August 1830, Philosophical Magazine Series 2, 9:51, 185-188, DOI: $10.1080 / 14786443108647585$

To link to this article: http://dx.doi.org/10.1080/14786443108647585

曲 Published online: 01 Jun 2009.

Submit your article to this journal ¿

山 Article views: 1

Q View related articles $\longleftarrow$ 
differt bulbo triplo majore; scapo basi solidiusculo non cavo; foliis (in caldario) non glaucescentibus; planis, non flexulis; florum pedunculis acuto-triangularibus, non teretiusculis, laciniis corollæ valdè albis, nec lacteis; tubo parùm longioribus, nec tubi longitudine; coronâ luteâ, nec aurantiâ, sesquiduplò nec triplò longioribus, et lævi, non plicata, ut in $\mathrm{Fl}$. Graca supra citatâ.

B. semiplena. Park. Pàrad. 85. fg. 2.

\%. plena. Park. Parad. 85. f. 3.4.

I dare not cite the beautiful figure of $t a b .1011$, in the $\mathrm{Bo}$ tanical Magazine, there calledNarcissus orientalis, var. Fl.Pl., because that plant shows eight flowers on its slender scape, which in that respect very well agrees; but I much doubt whether ours would ever have more than four or five. But it may be the double state of N. Tazetta of Fl. Gr. l. c., as the latter is there said to bear, when cultivated, many flowers.

If this conjecture proves correct, it will afford another instance of extremely similar species often occurring, as it were, in pairs; as in H. pracox of Tenore; and H. tenuiflora Nob. H. papyratia, Bot. Mag. 947, and H. Jasminea Salisb. et Nob. and many others.

That zealous and indefatigable Botanical Professor Dr. Schultes, assisted by his son Dr. Schultes, have greatly aided my endeavours to elucidate the Narcisse , by completely copying the whole of my last contribution to your excellent Magazine, on these much favoured plants, into the Addenda at the end of the 7th volume of their new edition of Linn. Syst. Veg. just published; which will doubtless spread the matter much more extensively than has hitherto been accomplished.

Chelsea, Feb. 7th, 1831.

XXXIV. On an Omission in Clairaut's Theory of the Equilibrium of a homogeneous Fluid; in some Remarks on the 56th Article of the "Bulletin des Sciences Mathematiques" for August 1830. By James Ivory, Esq. M.A. F.R.S.*

A $\mathrm{N}$ article in the Bulletin des Sciences Mathematiques for A August 1830, demands some observations from me.

We may begin with stating, in what Clairaut's theory of the equilibrium of a homogeneous fluid consists. 'This is a point not in any respect doubtful. According to the inventor of the theory and all other authors, two conditions are necessary and sufficient for the equilibrium. Supposing the equilibrium possible, it gives only one equation for determining the figure of the fluid. No accelerating forces are taken into

- Communicated by the Author.

N.S. Vol. 9. No. 51. Mar. 1831. 
account except those in action at the outer surface; and it is implied that the like forces, expressed by the same functions of the coordinates, and no others but these, act upon every interior particle of the mass. It follows from this view of the matter that the level surfaces depend entirely on the outer surface, and attempts are made to demonstrate this._-Vide Méc. Cél. livre iii. $\$ 22$.

On the other hand I contend that the figure of the fluid will depend upon the forces that actually urge every particle to move from its place: that, in a homogeneous planet in a fluid state, there are forces prevailing in the interior parts, which Clairaut has neglected: and that the equilibrium is impossible, unless such a figure of the fluid can be found as will set free the interior particles from those irregular forces. For this purpose the true figure of equilibrium must possess a property not deducible from Clairaut's theory; and this new condition, although it relates only to a particular problem, or to similar problems, it is usual to call my new principle of hydrostatics.

In the 27th volume of the Annales de Chimie et de Physique, p. 231, M. Poisson considers a homogeneous planet A B C, supposed fluid and in equilibrium. The interior surface $a b c$ is similar and similarly posited to the outer surface A B C, on which supposition the interior mass $a b c$ will be separately in equilibrium if the exterior stratum were taken away. The narrow canal $A a b B$ has its ends in the upper surface $A B C$, and the

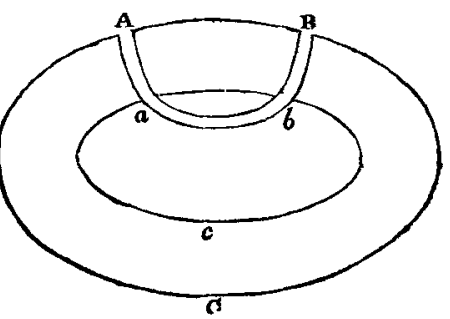
part between $a$ and $b$ is wholly within the interior mass $a b c$. M. Poisson proves that the equilibrium of the whole canal requires this equation,

$$
\delta=q-p, \text { or } p=q-\delta ;
$$

$p$ and $q$ being the weights of the canais $\mathrm{A} a$ and $\mathrm{B} b$, and $\delta$ the effort of the fluid in the canal $a b$, acting from $a$ to $b$ and caused by the attraction of the matter between the two surfaces. Now I observe that $M$. Poisson, by allowing that the stratum attracts the particles within it, and by calculating the pressure $\delta$ produced by its action, admits the omission made by Clairant, and in reality proves that the theory of that genmeter is insufficient for solving the problem. For there is no force at the outer surface $\mathrm{ABC}$, similar to the attraction 
of the stratum between the two surfaces upon the particles within the lower surface. Such an attraction therefore can have no place in the theory of Clairaut, which notices no forces except those in action at the outer surface. It is implied in the theory that the only forces urging a particle, whether situated in the surface or in the interior parts of the fluid, are the centrifugal force and the attraction of the whole mass; these forces produce the pressures of the canals $a \mathrm{~A}$ and $b \mathrm{~B}$; but they have no connection with the pressure $\delta$, which has quite a different origin. The theory of Clairaut is therefore insufficient for determining the equilibrium, because it leaves out some of the causes tending to change the figure of the fluid.

Further, I shall prove that the equation found by M. Poisson leads to two independent conditions for the figure of equilibrium. These conditions are, first, the equation of the outer surface, which is all that Clairaut's theory requires; secondly, the equality of pressure at all the points of every interior surface, as $a b c$, similar and similarly posited to the outer surface. For we may suppose that one end $a$ of the canal $a b$ remains fixed, while the other end $b$ is successively applied to every point of the surface $a b c$; in every position of the canal we shall still have the equation,

$$
p=q-\delta \text {; }
$$

from which it follows that $q-\delta$ is equal to the constant quantity of $p$ at every point of the surface. Now, $q$ being the weight of the canal $b \mathrm{~B}$, and $\partial$ the effort of the canal $a b$ towards $b$, caused by the attraction of the stratum, the intensity of pressure at every point of the surface $a b c$, will be the same. By means of this property, the equation of the surface $a b c$ will be derived from the equilibrium of the whole mass $A B C$; the same equation is deducible from the separate equilibrium of the interior mass $a b c$; and as the two equations must be identical, we thence obtain a condition which is independent of the outer surface of the fluid.

When the conditions for the equilibrium are more attentively investigated, it will appear that the attraction of the stratum upon the particles in the inside must produce no internal pressure. From this it follows that $\delta=0$ in M. Poisson's equation. In a paper in the Phil. Trans. for 1824, in which I first considered this problem, I have fulfilled what is physically required for the equilibrium by supposing that the stratum attracts every particle in the inside with equal force in all opposite directions. I have since found that this is not exact in all laws of attraction. But the fluid within the stratum 


\section{Rev.W.D. Conybeare on the Phanomena of Gealogy}

will be freed from all pressure caused by the attraction of the exterior matter, if the stratum exert no attractive force upon the particles situated in its lower surface; and this property, more general than the other, is indispensably required for the equilibrium. The paper alluded to must therefore be corrected by substituting the second property in place of the first; for which purpose nothing more is necessary than a change of the language in some parts, without any alteration of the calculations or the results.

In a homogeneous fluid in equilibrium it may be proved that the whole matter above any level surface must act upon the fluid below it by external pressure only, without exerting any accelerating force upon the particles that may cause internal pressure: and, as this is generel whatever be the nature of the accelerating forces, it may properly enough be called a new principle of hydrostatics.

The embarrassment attending the application of Clairant's theory arises from that author having failed to lay down the independent conditions of the equilibrium. Of the two conditions which are asserted to be necessary and sufficient for the equilibrium, one is included in the other: for it is easy to prove that the equation of the outer surface is deducible from the other condition.

Feb. 12, 1831 .

JAMEs Ivory.

XXXV. An Examination of those Phcenomena of Geology, which seem to bear most directly on theoretical Speculations. By the Rev. W. D. Conybeare, M.A. F.R.S. F.G.S. \&c.

[Continued from page 116.]

Part the Second.-Of Aqueous Action, and the excavaling Forces rohich have operated on the Strata.

THE phænomena of geology (to assign an adequate cause 1 for which, is the legitimate aim of theory) appear to me reducible to two classes:-1. those which indicate igneous action and the operation of elevating and dislocating forces on the strata; and, 2. those which indicate aqueous action and the operation of excavating forces. My former observations, which I would consider as constituting the first part of my present essay, have been dedicated to the first class of these phænomena; and I now propose to enter on the second. On these two heads, the difference between Mr. Lyell and myself amounts simply to this: Mr. Lyell believes that the forces which act on our planet have been, and are, ever constant and invariable; that therefore as to the first topic, all 